\title{
Michał Rzepka
}

Wyższa Szkoła Języków Obcych im. Samuela Bogumiła Lindego w Poznaniu

\section{Z prac nad edycją Diariusza legationis JWJMci Pana Strażnika Wielkiego Koronnego odprawionej roku $1732^{1}$}

W zbiorach Biblioteki Uniwersyteckiej w Poznaniu znajduje się rękopis o sygnaturze Rkp. 2325, będący zapisem poselstwa Józefa Sierakowskiego, strażnika wielkiego koronnego, do Turcji, odbytego w latach 1732-1733. Na jego kartach dzień po dniu opisane zostały: przebieg podróży legata do Stambułu, sam pobyt i przebieg misji oraz droga powrotna do kraju.

Rękopis składa się z 96 stron folio, z czego 90 stron tekstu spisano w układzie diariuszowym dzień po dniu. Autor systematycznie każdy wpis zaczynał od zaznaczenia daty dziennej, stąd precyzyjnie można ulokować w czasie poszczególne wydarzenia przedstawione w relacji. Pierwszy wpis informujący o rozpoczęciu podróży opatrzony został datą 23 sierpnia 1732 roku, ostatni zaś zapis nosi datę 6 maja 1733 roku i informuje o zakończeniu podróży, pożegnaniach z jej uczestnikami i spiesznym wyjeździe Józefa Sierakowskiego, strażnika wielkiego koronnego, do Warszawy, w celu wzięcia udziału w sejmie konwokacyjnym zwołanym po śmierci Augusta II.

Dokument ten pochodzi z biblioteki ordynacji Czerniejewo-Radomice ustanowionej przez hr. Rajmunda Skórzewskiego, o czym świadczy stempel biblioteczny umieszczony na trzeciej stronie (tytułowej) rękopisu². Widnieje tam również adnotacja wskazująca na datę pozyskania go do zbiorów czerniejewskich (1826), umieszczona na dole karty. Strony pierwsza i trzecia zawierają także dopiski (dokonane najprawdopodobniej podczas katalogowania zbiorów

1 Tekst został wygłoszony na seminarium dedykowanym pamięci Profesora Wojciecha Ryszarda Rzepki Polszczyzna doby staro- $i$ średniopolskiej, Poznań, 21-23 stycznia 2019 roku.

2 Okrągły stempel biblioteczny z napisem: SIGIL: BIBLIOTH.ORDIN:RADOMICE:CZER$N I E V$-is jest jednym z trzech rodzajów stempli występujących na zachowanych zbiorach czerniejewskich [zob. Nowicki 2004: 55]. 
bibliotecznych Skórzewskich przez ks. Ignacego Polkowskiego 3 , który przebywając w ich dobrach w latach 1866-1877, skatalogował prawie jedną czwartą księgozbioru, czyli ok. 12 tys. dzieł [Szulc-Golska 1929: 241] ]), zapisane inną ręką i piórem niż pozostała część dokumentu. Na stronie pierwszej zanotowano uwagę dotyczącą treści dokumentu: „Poselstwo do Turcji”, na stronie trzeciej zaś pod tytułem Diariusz legationis Jaśnie Wielmożnego Jegomości Pana Strażnika Wielkiego Koronnego odprawionej roku 1732 dodano: do Stambutu. Ponadto na drugiej stronie okładki znajdują się wpisane numery katalogowe, pierwszy z nich, 1510, zapisany został czerwoną kredką, kolejne to wpisane ołówkiem 9/2333 (przekreślone) oraz aktualny numer akc 2325. Również trzecia strona okładki zawiera zapisany ołówkiem u dołu numer s.k.k.108.

Oprawa dokumentu jest z pewnością XIX-wieczna. Okładkę poszytu stanowi sztywna oprawa ćwierćpłócienna, której okładziny oklejone są papierem marmoryzowanym, grzbiet zaś ciemnozielonym welurem. Wewnętrzną stronę okładki stanowi wyklejka $\mathrm{z}$ tego samego papieru, na którym spisano dokument. Na grzbiecie znajdują się pozostałości po naklejce wykonanej z papieru w kolorze złotym.

\section{O rękopisie}

Rękopis Diariusza legationis JWJMci Pana Strażnika Wielkiego Koronnego odprawionej roku 1732 wydawać by się mógł jednym z wielu przykładów literatury pamiętnikarskiej związanej z polskimi poselstwami do Turcji w XVII i XVIII wieku, obok relacji z takich legacji, jak Stanisława Chomentowskiego z lat $1712-1714^{5}$, Rafała Leszczyńskiego z lat 1699-17006, Jana Gnińskiego

3 Praca Ignacego Polkowskiego (1833-1888) zaowocowała nie tylko częściowym skatalogowaniem zbiorów Skórzewskich, ale również zebraniem cennych materiałów, z których z pewnością korzystał, przygotowując Żywot Mikołaja Kopernika (wydany w Gnieźnie w 1873 roku), Album Mikołaja Kopernika. Album. Wydane staraniem Towarzystwa Przyjaciót Nauk w Poznaniu w czterechsetna rocznicę urodzin Mikołaja Kopernika (Gniezno 1873), Kopernikijana czyli materyały do pism i życia Mikołaja Kopernika (t. 1-2, Gniezno 1873, t. 3, Gniezno 1875).

4 Na Bożennę Szulc-Golską powołuje się również, przytaczając podane wartości, Ryszard Nowicki [2004: 59].

5 Poselstwo wielkie Jaśnie Wielmożnego Stanisława Chomentowskiego, wojewody mazowieckiego od Nayiaśnieyszego Augusta II, krola polskiego, xiążęcia saskiego elektora y Rzeczypospolitey do Achmeta IV, soltana tureckiego wielkiego z petna moca posła z szczęśliwym skutkiem przez lata 1712, 1713, 1714 odprawione, potomnych czasow pamięci y wdzięczności podane wrzetelnym iego opisaniu przez x. Franciszka Goscieckiego, Soc. Jesu., Lwów 1732 [pisowania oryginalna].

6 Poselstwo Rafala Leszczyńskiego do Turcji w 1700 roku. Diariusze i inne materiały, przygotowała I. Czamańska przy współpracy D. Zydorek, Leszno 1998. 
z lat 1677-1678 [Pułaski 1907], Hieronima Radziejowskiego z roku 1667 [Przyboś, Żelewski, oprac. 1959] czy Wojciecha Miaskowskiego z roku 1640 [Przyboś, oprac. 1985]. Dwa jednak czynniki sprawiają, że wyróżnia się on spośród innych znanych wspomnień.

Przede wszystkim jest to diariusz do tej pory nieznany. Dysponujemy wyłącznie dwoma jego wariantami. Pierwszym jest omawiany tu rękopis ze zbiorów Biblioteki Uniwersyteckiej UAM, który nie jest tekstem oryginalnym, ale odpisem z przełomu XVIII i XIX wieku (na pewno powstałym przed końcem 1826 roku). Drugi znany wariant to relacja z wyprawy, zamieszczana na łamach „Kuryera Polskiego” („KP”) w latach 1732-17337, a więc współcześnie do odprawianego przez Józefa Sierakowskiego poselstwa. Inne odmiany tekstu, ani w całości, ani w części, nie zostały do tej pory ujawnione. Diariusz pomijany jest także w historiografii. Fakt publikacji opisu poselstwa na łamach „Kuryera Polskiego” odnotowuje zdawkowo Władysław Konopczyński w monografii Polska a Turcja 1683-1792 [Konopczyński 2013: 91]. Z kolei Teodor Żychliński, prezentując ród Sierakowskich h. Ogończyk z Waplewa, wspomina Józefa Sierakowskiego jako ich zasłużonego przodka, odnotowując fakt, że w zbiorach rękopisów biblioteki waplewskiej znajduje się diariusz z jego poselstwa do Stambułu [Żychliński 1879: 281] ${ }^{8}$. Poza tymi przypadkami brak w literaturze jakichkolwiek innych śladów istnienia innych wariantów tekstu.

Drugim czynnikiem świadczącym o wyjątkowości tej relacji jest moment w dziejach, w którym poselstwo zostało odprawione. Józef Sierakowski, strażnik wielki koronny, poseł Augusta II do sułtana Mahmuda I, wyruszył w drogę w sierpniu 1732 roku. Jest to czas ułożonych już stosunków Polski z Turcją i pokojowej koegzystencji obu sąsiadujących ze sobą krajów. Śmierć króla w lutym 1733 roku uruchamia na nowo walkę dwóch najsilniejszych stronnictw - przysłowiowych Sasa i Lasa - o poparcie ich kandydatów, w rezultacie prowadzi do trwającej do 1736 roku wojny domowej. W sposób oczywisty wpływa także na celowość misji poselskiej przebywającej w Stambule. Diariusz ukazuje ten niezwykle ciekawy moment związany ze śmiercią władcy

7 Relacja z podróży Józefa Sierakowskiego do Stambułu ukazała się w 15 numerach „Kuryera Polskiego": w roku 1732 były to numery: CXLII, CXLIII, CXLV, CXLIX, CL; w roku 1733 - CLIX, CLX, CLXI, CLXIV, CLXV, CLXVI, CLXXIII, CLXXV, CLXXVIII, CLXXX.

8 Tekst Teodora Żychlińskiego zawiera elementarne błędy. Józef Sierakowski był posłem Augusta II, nie zaś Augusta III, jak zapisał Żychliński; imię pierwszej żony strażnika koronnego to Elżbieta, nie zaś Teresa, jak w tekście; dziedziczna posiadłość Sierakowskiego to Żabcze, nie zaś Żabce, jak chce autor. 
i rosnącą dynamiką wydarzeń politycznych w kraju z perspektywy przebywającego w Stambule poselstwa. Możemy prześledzić natychmiastowe decyzje o zmianie lojalności politycznej Józefa Sierakowskiego i jego otoczenia, jego starania o pozyskanie poparcia dla Stanisława Leszczyńskiego, podejmowane przez dyplomatów innych krajów (zwłaszcza Rosji) próby pozyskania informacji pozwalających im szacować rozkład sił i szanse pretendentów do tronu. Możemy zaobserwować linie sojuszy i antagonizmów ujawniane w kontaktach między ambasadorami i posłami w Stambule oraz postawy polityczne wobec obu polskich stronnictw.

Nie bez znaczenia dla wartości dokumentu są również inne informacje, które przekazuje - dotyczące organizacji i logistyki dużej wyprawy do Turcji w pierwszej połowie XVIII wieku, życia codziennego poselstwa, obyczajów i ceremoniału dyplomatycznego.

\section{Problematyka badań}

Edycja diariusza wymagała przeprowadzania badań w kilku obszarach, które przenikają się wzajemnie i łączą się ze sobą.

Pierwszym zagadnieniem w pracy z dokumentem było ustalenie jego oryginalności i pochodzenia oraz autorstwa. Przedmiotem badań były zarówno jego cechy zewnętrzne, proweniencja, jak i język oraz treść samej relacji.

Drugi obszar badań dotyczy biografii posła, Józefa Sierakowskiego h. Dołęga, strażnika wielkiego koronnego. Dysponujemy co prawda hasłem w Polskim Stowniku Biograficznym [Szklarska 1996-1997: 268-269], ale pozyskanie nowych, niewykorzystanych w PSB źródeł pozwoliło ten biogram poszerzyć.

Kolejnym zagadnieniem było osadzenie relacji z wyprawy poselskiej w kontekście historycznym i wskazanie jej celów. W tym zakresie mieści się również komentarz do edycji obejmujący wyjaśnienia dotyczące osób, miejsc i okoliczności związanych z relacją oraz objaśnienia terminów, zwłaszcza pochodzących z języków obcych.

Porównanie poselstwa Józefa Sierakowskiego z innymi relacjami z misji dyplomatycznych do Stambułu stanowiło kolejny obszar badań.

\section{Oryginalność dokumentu}

Rękopis Diariusza legationis... - poza stemplami bibliotecznymi księgozbioru ordynacji Czerniejewo-Radomice oraz notatką odręczną wskazującą na pozyskanie go do zbiorów Skórzewskich w 1826 roku - nie zawiera żadnych innych informacji dotyczących daty jego powstania, miejsca pochodzenia, autora czy powiązanych innych dokumentów. 
W ustaleniu faktu, że mamy do czynienia z odpisem, a nie oryginalnym dokumentem, przydatna była przede wszystkim analiza tekstu od strony graficznej. Ujawnione zostały przypadki błędów pisarskich poprawianych ręką piszącego, a polegające na: powtórzeniach wyrazów lub całych zdań, pomyłkach pisarskich, przestawionym i skorygowanym szyku zdania.

W tekście odnaleźć można także miejsca, w których piszący umieszcza dwie alternatywne formy zapisu jednego wyrazu bądź też pozostawia wolne miejsce, co świadczyć może, że przepisując, nie był pewien poprawności odczytania.

Błędy takie to typowe omyłki pisarskie, wynikające z mechanicznej czynności przepisywania. Wystąpienie ich w tekście świadczy o tym, że badany dokument to najpewniej kopia. Analiza graficznej strony pisma, jego duktu, organizacji i struktury dokumentu, dobrej jakości pióra wskazuje na osobę wprawioną w pisaniu, być może zawodowego pisarza.

W kwestii ustalenia czasu powstania dokumentu na przełom XVIII i XIX wieku przydatna była przede wszystkim źródłoznawcza kwerenda zewnętrzna dokumentu. Dobrej jakości papier stemplowy noszący filigran główny „Pro patria” [Siniarska-Czaplicka 1983: 32] mógłby wskazywać na produkt papierni z Jeziornej [Siniarska-Czaplicka 1977: 238], jednak brak charakterystycznych dla niej literowych filigranów pomocniczych oraz występujący na papierze filigran pomocniczy „D\&C Blauw” wskazują na holenderską papiernię De Herder w Wormerveer [Voorn 1960: 543-544]. Biorąc więc pod uwagę papier z jednej, a wpisy biblioteczne z drugiej strony, można przyjąć, że dokument nie mógł powstać wcześniej niż w 1744 roku i nie później niż w 1826 roku.

Miejscem powstania rękopisu było zapewne Waplewo Wielkie na Pomorzu należące do Sierakowskich h. Ogończyk. Kwerenda zewnętrzna, w tym jakość papieru, poświadczona duktem pisma i redakcją rękopisu wprawa piszącego oraz dobrej jakości narzędzia pisarskie wskazywałyby, że dokument wytworzony został właśnie w ośrodku dworskim. Na Waplewo Wielkie zaś wskazują inne przesłanki, w tym dane genealogiczne:

a) właściciele Waplewa, Sierakowscy h. Ogończyk, spokrewnieni byli po kądzieli z Józefem Sierakowskim h. Dołęga, strażnikiem wielkim koronnym, posłem Augusta II do Stambułu;

b) w pałacu w Waplewie znajdowały się pamiątki rodzinne po Józefie Sierakowskim, w tym szkatuła, jaką otrzymał od sułtana, obraz przedstawiający wjazd posła do Stambułu, które w roku 1881 na własne oczy widział Stanisław Tarnowski i opisał w drugim tomie swego dzieła Z wakacyi. (Prusy Królewskie) [Tarnowski 1894: 277]”;

9 Stanisław Tarnowski przebywał w Waplewie od 22 do 26 lipca 1881 roku. 
c) w bibliotece Sierakowskich znajdował się egzemplarz relacji z podróży na dwór sułtański, o czym informuje Teodor Żychliński, opierając się na wiadomościach od Adama Lwa Sołtana, opiekuna tej biblioteki opracowującego i katalogującego jej zbiory [Żychliński 1879: 281].

Pośrednio na Waplewo Wielkie jako miejsce powstania dokumentu wskazywać może koligacja Sierakowskich ze Skórzewskimi. Wnioskować można, że Rajmund Skórzewski miał świadomość związków Sierakowskich z Józefem, strażnikiem wielkim koronnym, wiedział o posiadanym przez nich diariuszu i pozyskał odpis do swoich zbiorów, które profilował pod kątem dziejów i osiągnięć polskiej dyplomacji [Nowicki 2004: 52; zob. Szulc-Golska 1929: 227-269]. Właśnie z tych zbiorów pochodzi badany tekst.

\section{Pochodzenie rękopisu - cztery warianty tekstu}

Ponieważ, jak już wspomniano, badany rękopis jest odpisem, nie można pozostawić go bez próby ustalenia jego pierwowzoru. Pojawiła się więc konieczność zebrania informacji o oryginalnej wersji dokumentu oraz jej autorze.

Analiza danych dotyczących wzmiankowanych i istniejących wersji relacji pozwala stwierdzić, że były co najmniej cztery takie wersje.

Pierwsza wersja to wariant czerniejewski w zbiorach Biblioteki Uniwersyteckiej UAM, nazwijmy go „C”, którego postać materialną posiadamy.

Druga to, jak można zakładać, jego pierwowzór - znajdująca się w Waplewie Wielkim i wzmiankowana w literaturze wersja, którą nazwać możemy „W”. Podana data roczna w pierwszym wpisie diariusza, a także fragmenty retrospektywne wskazują na dystans czasowy, jaki dzieli powstanie „W” od wyprawy. Obecnie uznać należy ten wariant za zaginiony, niemniej istniał na pewno, gdyż wspominany jest w relacji Teodora Żychlińskiego.

Należy przyjąć, że wariant „C” jest kopią wariantu „W”. Przyglądając się strukturze tekstu, zauważyć można, że nie jest ona jednorodna. Diariusz legationis... charakteryzuje się szczegółowością prezentowanych danych oraz systematycznością wpisów dziennych. Jednak część z nich jest obszerna i narracyjnie zredagowana, część natomiast lakoniczna i zapisana hasłowo. W tekście znajdziemy również odwołania do innych dokumentów. Przytaczane przemówienie polskiego posła zawiera odwołanie nomen nominandum, które nie jest częścią przemowy, ale zastosowane zostało dla skrócenia zapisu i oznacza konieczność wymienienia w tym miejscu imienia i tytułów Augusta II. Taki zabieg nie powinien się pojawić w zredagowanym tekście, jest to więc wskazówka, że relacja powstała na podstawie kilku źródeł. Najprawdopodobniej fragment z przemówieniem pochodzi z instrukcji poselskiej i z niej jest cytowany. Wnioskować więc można, że podstawą redakcji rękopisu „W” 
(a z niego „C”) był jeszcze inny wariant relacji - nazwijmy go „A” - który mógł być bądź to diariuszem tworzonym na bieżąco podczas wyprawy, bądź to zbiorem dokumentów poselstwa, składającym się z diariusza, instrukcji poselskiej, kopiariusza listów i mów itp. On również nie jest znany w postaci materialnej, jednak zestaw dokumentów poselstwa i diariusz prowadzony na bieżąco, choćby dla celów sprawozdawczych po powrocie legacji istniały z pewnością. Świadczą o tym nie tylko wspomniane już odmiany rękopisu „W” i „C”, ale także kolejna wersja relacji, której z tamtymi utożsamiać nie można. Mowa tu o niezwykle ważnej dla ustalenia pochodzenia i wzajemnych związków między wersjami diariusza, sygnalizowanej już publikacji na łamach „Kuryera Polskiego” - pomijanej i zapomnianej w historiografii.

Porównując wariant czerniejewski „C” z relacją „Kuryera Polskiego”, już na pierwszy rzut oka dostrzec można, że są one sobie bardzo bliskie, fragmentami wręcz identyczne, różnią się w zasadzie w faktograficznych detalach, np. jeśli chodzi o podawaną liczbę chorągwi wyprowadzonych na powitanie Józefa Sierakowskiego w Kamieńcu Podolskim (,$C ”=6$; „KP” = 7):

[...] gdzie zbliżonemu, pod ziemny zamek obviam wyszedł magistrat kamieniecki, pod sześcią chorągwiami zgromadzonemi [...]. [Rękopis „C”, karta 4 recto]

[...] Imć Pan Strażnik Kor. procedebat, gdzie magistrat kamieniecki pod 7. chorągwiami cechowemi przy trąbach y kotłach wyszedłszy [...]. [„,Kuryer Polski" 1732, nr CXLII, s. 210]

Innym przykładem drobnej nieścisłości jest podawana liczba stołów na przyjęciu w Kamieńcu („C” = 7; „KP” =6):

[...] a zastawszy splendide adornowane stoły, solennissime traktował, sam prawie u każdego stołu, których było siedm, praesens będąc i ochoty dodając przy ślicznej trąb i innej muzyki wojskowej melodii [...]. [Rękopis „C”, karta 4 recto]

[...] po których Ichmciów do siebie zaprosiwszy u 6. stołów przy wdzięcznych koncertach kapeli lautissime częstował [...]. [„,Kuryer Polski” 1732, nr CXLII, s. 210]

Nieścisłości pojawiają się również przy wyliczaniu powitalnych salutów $(, \mathrm{C} "=17 ;$, ,KP” = 18): 
[...] a gdy już ad maenia fortecy samej (varia procedente musica) i bramom chocimskim zbliżał się, z dział ognia huczno razy siedemnaście basza dać rozkazał na przywitanie [...]. [Rękopis „C”, karta 6 recto]

[...] gdy wjeżdżał do zamku do baszy chocimskiego, z armat wielkich 18. razy ognia dano [...]. [„,Kuryer Polski” 1732, nr CXLIII, s. 216]

Wariant „KP” nie zawiera jednak wszystkich informacji z wariantu „C”, odnosi się wrażenie, że jest on jego wersją, redagowaną i skracaną na potrzeby druku na łamach „Kuryera Polskiego”. Tak więc ani „C”, ani jego pierwowzór „W” nie mogły powstawać na podstawie „KP”, gdyż zawierają wiele bardziej szczegółowych informacji. Ponieważ jednak „KP” zamieszczany był w czasie niemal rzeczywistym do legacji Sierakowskiego, natomiast wariant „C”, a tym samym jego pierwowzór „W" redagowane były z pewnego dystansu czasowego, można przypuszczać, że pochodzą właśnie od wariantu „A”. Co ciekawe, „KP” zawiera także informację, której nie podaje „C”. Datowana jest ona już po wyjeździe Józefa Sierakowskiego w drogę powrotną i dotyczy egzekwii za zmarłego Augusta II, jakie odprawiono w Stambule staraniem pozostawionego w roli rezydenta Jana Stadnickiego:

Z Konstantynopola d. 16 April. JMć P. Strażnik W. Kor. po zakończonej szczęśliwie funkcyi poselskiej u Porty, nieśmiertelną w tych krajach zostawił pamiątkę, kiedy albowiem stąd wybierającego się do ojczyzny, zaszła niepocieszna nowina de fatis śp. Króla JMci, tedy Imć P. Strażnik W. Kor. pokazując to, że każdy monarcha w sercach polskich vivit post fata superstes, Xdzu superiorowi generalnemu $\mathrm{S}$. Iesu missionum w Grecyi dał znaczną summę na exekwie za śp. Króla Imci, którym nie mogąc sam adesse tak dla publicznych jako i prywatnych interessów, Imci P. Stadnickiemu kasztelanicowi bełzkiemu tu na rezydencyi będącemu wszelką dyspozycją tegoż aktu zlecił. Pomienione exekwie dnia dzisiejszego z solenną ceremonią odprawiły się w Kościele X. Jezuitów, gdzie cały kościół żałobą obity i samemi świecami (gdyż tu illuminacyi z lamp czynić zwyczaju nie masz) był illuminowany, w kopule był cyrkuł jeden rzęsistym światłem napełniony a koronę nieśmiertelności reprezentujący, drugi semi cyrkuł reprezentował okrąg światła, nad którym portret zeszłego Króla Imci między herbami koronnym, litewskim i saskim z różnemi inskrypcjami był wystawiony, wposrzodku kościoła wystawiony był katafalk wielkim mnóstwem świec jarzęcych i pochodni otoczony, na wierzchu złocista korona, sceptrum i ręka z mieczem jus gladij et supreme justitiae repre- 
zentująca leżały, przed katafalkiem na żałobnym krześle po prawej stronie siedział poseł francuski; po lewej zaś Imć P. kasztelanic bełzki, którzy Ichmć z całą assystencją w żałobę przybrani byli, gdzie się oraz znajdowali sekretarze i tłumacze ministrów chrześcijańskich. Rezydent cesarski dla pewnych racyi, poseł wenecki dla słabości zdrowia, posłowie angielski, holenderski i moskiewski rezydent propter disparitatem religionis et ritus przytomnemi nie byli. Imć X. arcybiskup kartageński jako vicarius patriarchalis $\mathrm{w}$ asystencyi całego duchowieństwa tu znajdującego się pontificaliter celebrował. Po skończonych ceremoniach IMć P. Stadnicki kasztelanic bełzki tegoż IMci X. arcybiskupa tudzież IMci Pana posła francuskiego i innych IchMciów na tym akcie przytomnych w kolegium xx. jezuitów solennie częstował, potym zaś Imć X. Arcybiskup cum suo clero tudzież zakonnicy z rąk x. superiora soc. Iesu podług dyspozycyi samego Imci P. Strażnika Kor. in scripto danej hojne elemozyny odebrali. [„,Kuryer Polski” 1733, nr CLXXX, s. 421]

\section{Sprawa autorstwa}

W obszarze badań nad rękopisem pozostała jeszcze kwestia autorstwa. Przy braku innych wskazówek należało się oprzeć na analizie języka, którym spisany został tekst diariusza.

\subsection{O związkach autora z Józefem Sierakowskim}

Niewątpliwie autor był uczestnikiem poselstwa i naocznym świadkiem wielu wydarzeń. Opisuje je w detalach możliwych do zaobserwowania wyłącznie na podstawie własnych doświadczeń.

Z pewnością brał udział w spotkaniach oficjalnych i audiencjach. Pozostawił z nich relacje zawierające szczegółowe opisy okoliczności, miejsc, osób, przebiegu spotkań oraz zacytowane rozmowy i wypowiedzi.

Autor brał też udział w mniej formalnych spotkaniach - opisał interesujące miniatury obyczajowe, jak choćby wizytę posła weneckiego, odpowiednio „utraktowanego" i ,podochoconego” kozacką bandurą, tak iż po przyjęciu nie był w stanie o własnych siłach wrócić do łodzi i musiał być odniesiony przez nie mniej wesołych swoich towarzyszy ${ }^{10}$. Innym przykładem mogą być opisane doświadczenia posła angielskiego, który wstawszy następnego dnia po przy-

10 Wpis z dnia 1 lutego 1733 roku: „Tandem zabawiwszy się ad vesperam jedni titubantes et praecipue paicy i masztalerze, dla których konwiami jegomość pan Gostyński marszałek dworu jaśnie wielmożnego jegomości pana strażnika wielkiego koronnego kazał nosić wino i jeść dawać co się komu podobało, a drudzy variis linguis majoris eminentiae loquentes szli do kaików i samego jegomości pana posła wesołego niesiono po węgierskim winie". 
jęciu u polskiego legata, odmówił obiadu i „tylko się kawy i wotki napiwszy i chleba z masłem zjadłszy", udał się do swojej rezydencji ${ }^{11}$.

O bliskości autora z Józefem Sierakowskim świadczy jego znajomość osób z otoczenia strażnika wielkiego koronnego, i to nie tylko towarzyszy z chorągwi pancernej, ale również członków rodziny czy służby. W relacji czytamy: „umarł nagle Błażej, piwniczny”12, w innym zaś miejscu: „któremu do usługi przydano Konstantego pachołka na noc i Kurbanowskiemu jegomościnemu przykazano, żeby pana swego doglądał i czego tylko potrzeba subministrował"'13. Jednocześnie tak detalicznej wiedzy o służbie innych członków poselstwa autor nie ujawnia. Potwierdzałoby to jego przynależność do otoczenia Sierakowskiego właśnie.

Szczegółowość i mnogość informacji dotyczących wydarzeń z udziałem Józefa Sierakowskiego oraz wykazywana znajomość ludzi z otoczenia strażnika wielkiego koronnego, jego przyzwyczajeń i spraw majątkowych wskazują, że autor był osobą z najbliższego otoczenia posła, zapewne jego osobistym sekretarzem. Jednocześnie wykluczyć można, że autorem był sam Sierakowski, gdyż niekiedy informuje o wydarzeniach, których był świadkiem, a odbywających się podczas nieobecności strażnika wielkiego koronnego.

\subsection{O języku autora Diariusza legationis...}

Język, jakim posługuje się autor, zaświadcza o elementach wspólnego systemu wartości stanu szlacheckiego. Zaliczyć do nich należy: rustykalność, gościnność, etykietę, kult urzędu i tytułowanie, odwoływanie się do tradycji antycznych, swoiste pojęcie honoru, religijność Polaka-katolika, megalomanię i ksenofobię narodową [Rzepka, Walczak 1992: 180-181]. Jego język przejawia również cechy charakterystyczne dla socjolektu szlacheckiego. Nie zawiera może porównań i konstrukcji retorycznych cechujących teksty o charakterze oficjalnym, ceremonialnym, ale ma elementy stanowiące czynnik wyróżniający socjolekt szlachecki spośród innych socjolektów. Wojciech Ryszard Rzepka i Bogdan Walczak uznają za nie: rozbudowaną warstwę zwrotów grzecznościowych, bogatą i subtelnie wycieniowaną tytulaturę, frazeologię i metaforykę nawiązujące do życia wojskowo-obozowego i innych charakterystycznych cech kulturowości szlacheckiej, makaronizowanie, stosowanie słownictwa

11 Wpis z dnia 2 marca 1733 roku: ,[...] a poseł JMć angielski evapulata crapula,circa decimam wstawszy, jeść obiadu renuit, tylko się kawy i wotki napiwszy i chleba z masłem zjadłszy [...]".

12 Wpis z dnia 3 grudnia 1732 roku.

13 Wpis z dnia 3 grudnia 1732 roku. 
rolniczo-myśliwskiego, wojskowego i społeczno-politycznego [Rzepka, Walczak 1992: 184-187].

Pierwszą, najbardziej widoczną cechą języka autora jest maniera makaronizowania. Wtrącenia łacińskie stanowią znaczną część tekstu, tworząc zarówno zwarte zdania, jak i pojedyncze wtręty w zdaniu. Obok tekstu łacińskiego w tekście reprezentowane są również charakterystyczne dla makaronizowania konstrukcje składniowe wpływające na szyk zdania i łamiące zasady gramatyki i składni polskiej, np. w notatce z 30 sierpnia zapisano:

tandem jaśnie wielmożny jegomość pan strażnik wielki koronny, pod znaczkiem, na koniu dzielnym lente postępował passu z niemałą zgromadzonych ichmościów przyjaciół, z różnych województw i ziem, na pożegnanie, liczbą, którego już teraz sequebatur komenda cudzoziemska wojska w tęż drogę in assistentiam przydana od jaśnie wielmożnego jegomości pana wojewody i generała ziem mazowieckich, regimentarza wojsk koronnych generalnego.

Zastosowana tu konstrukcja sequor + Accusativus nie pozwala na znalezienie właściwego polskiego ekwiwalentu. Sens można oddać tylko opisowo przez dodanie komentarza, np.: „,którego już teraz sequebatur [podążała, tu w znaczeniu jechała za nim] komenda cudzoziemska wojska”.

Kolejnym charakterystycznym elementem języka autora Diariusza legationis... jest wplatanie słownictwa związanego z wojskowością i wojskowo-obozowym stylem życia. Liczne przykłady po części wynikają z faktu, że Józef Sierakowski był pułkownikiem pancernym i w swym otoczeniu poselskim miał licznych towarzyszy spod znaku pancernego, sam też podążał pod znakiem „szachownicy z krzyżem”, był typowym przedstawicielem ówczesnego stanu szlacheckiego, dla którego „wojskowa skóra” była drugą naturą. Autor niewątpliwie miał również doświadczenia związane z wojskowością, o czym świadczy jego język, szczególnie te fragmenty, w których terminologia wojskowa nie wynika z opisywanych obrazów czy wydarzeń, ale wskazuje na jego obeznanie z tematem. 27 sierpnia zapisano:

[...] któremu jaśnie wielmożny jegomość pan strażnik, jako veteraneo militi ${ }^{14}$, et socio labor[um] et dolor[um], ex imo cordis mile podziękowawszy, ulterius do wojska processit, dokąd przybywszy zastał chorągwie okryte wszystkie i ichmościów towarzystwo w pancerzach i pocztowych more quo competit przybranych.

14 Veteraneo militi (łac.) - 'doświadczonemu żołnierzowi'. 
Wpis z 29 sierpnia potwierdza obeznanie autora z terminologią wojskową:

Przybył też i jegomość pan Kazimierz Gumowski, towarzysz znaku pancernego wielmożnego jegomości pana starosty stobnickiego, komendę mający nad forwachtami i promami $[\ldots]$.

W notatce z 2 lutego autor pozostawia czytelnikowi opis zwiedzanej rezydencji tureckiego dostojnika. Opisując wielkość jednego z pomieszczeń, stwierdza, że jest tak duże, iż można by w nim urządzać strzelania z łuku. Ćwiczenia takie służyły rozwijaniu żołnierskiej sprawności:

pan strażnik wielki koronny wyszedł lustrando habitaculum, gdzie był na sali, która się tam intro w saraju jego znajduje, tantae magnitudinis ${ }^{15}$, iż w niej wybornie do czapki z luku strzelać można.

O obeznaniu autora $\mathrm{z}$ rzemiosłem wojskowym świadczy również wpis z 1 maja stanowiący relację z powitania wracającego posła w Tarnopolu:

tam ognia z armat i szańców z zamku kilka razy dano, ale że incautus bo pijany puszkarz, niewychędożywszy armaty, prochu w nią iterato wsypał, a relicta scintilla, a od niej zapalonego prochu rękę po łokieć stracił, kiedy taż sama szufta czyli stąpel mu ją oderwała.

Kolejne cechy języka autora także wpisują się w ogólną charakterystykę socjolektu szlacheckiego i kultury stanowej. W pozostawionych przez niego wpisach dziennych wyróżnić można takie fragmenty, które poświadczają związanie ze sprawami gospodarstwa i roli, stosowanie odwołań do antyku i zainteresowanie starożytnością, ksenofobiczne nastawienie do innych kultur i religii.

Odwołania do antyku wykorzystuje autor, opisując postaci. 13 września, relacjonując spotkanie z mołdawskim kanclerzem wielkim, tak charakteryzuje jego osobę:

[...] obviavit wprzódy jegomość pan Konstanty Kostaki, kanclerz wielki ziemi mołdawski, antiquissimae Dacor[um] familiae Romanis proavis atavos suos ducens $^{16}$, honesto stipatus comitatu, człowiek niebardzo sędziwy, ale powagi pełny $[\ldots]$.

15 Tantae magnitudinis (łac.) - 'takiej wielkości'.

16 Antiquissimae Dacorum familiae Romanis proavis atavos suos ducens (łac.) - 'wywodzący swoich przodków z dziada pradziada od bardzo starej, rzymskiej rodziny Daków'. 
Wywodzenie genealogii od starożytnych rodów rzymskich jest typowe i charakterystyczne dla sarmackiej kultury, zabieg ten miał na celu podniesienie znaczności i godności osoby legitymującej się tak starożytnymi korzeniami.

Jak wspomniano, w diariuszu znajdują się również wpisy świadczące o orientacji autora w sprawach gospodarczych. Wielokrotnie, opisując mijane wsie, zwraca uwagę na stan pól i gospodarność mieszkańców. We wpisie z 28 września zauważał:

[...] ruszył szczęśliwie ku Dunajowi gdzie ludzie konie i wozy przeprawiły się na kępę, której od Izmaila jadąc na trzy jest i dalej mile wszerz, na której ogrody, owoce różne i winogrady, et quiq[ue] frumenta ac segetes, nec non fructa $^{17}$ mają [...].

Natomiast 9 października zapisał:

[...] bo widzieć było circa viam, którą jachał i stare oraniny i ściernie gęsto zboż pożętych i nowo zasiane role, jednak godzin pięć jadąc, dwie tylko wsie patrzały na nas $[\ldots]$.

Autor zainteresowany jest też sprawami gospodarczymi niezwiązanymi z rolą. Zwiedzając port w Izmaelu, miał okazję oglądać wyposażenie statków handlowych. Tak opisał to 24 września:

Potym, od tegoż metewillego prowadzony na okręty dunajskie, na których varia ad navigationis artem requisita et instrumenta ${ }^{18}$ jako kompasy cum acu magnetica ${ }^{19}$, żagle, maszty, aliaq[ue] propio suo nomine vocitanda ${ }^{20}$, nawet cellas in inferiori parte existentes, ac etiam niewolników utriusq[ue] sexus, na przedaż ex Georgia przywiezionych sam prowadząc praesentavit $[\ldots]$.

W tekście diariusza odnaleźć można także wpisy świadczące o uprzedzeniach autora do inności kulturowej i religijnej ludzi zamieszkujących mijane

17 Et quique frumenta ac segetes, nec non fructa (łac.) - 'i jakiekolwiek zboża, plony i inne owoce'.

18 Varia ad navigationis artem requisita et instrumenta (łac.) - 'różne do sztuki nawigacji przedmioty i instrumenty'.

19 Cum acu magnetica (łac.) - 'z igłą magnetyczną'.

20 Aliaque propio suo nomine vocitanda (łac.) - 'I inne rzeczy, które własnym trzeba byłoby zwać imieniem'. 
ziemie i manifestujące poczucie wyższości tego, co dla niego rodzime. Pierwsza wyraźna uwaga odnosi się do nieporozumień związanych z aprowizacją poselstwa przez Turków; 2 września autor zapisał:

Dziwił się temu jaśnie wielmożny jegomość pan strażnik wielki koronny, że jako gens parca et pauca in loquendo ${ }^{21}$, tak też parco et pauco ${ }^{22}$ chce kontentować prowiantu et minus tym distractus ad expeditiones sese contulit aż do wieczora $[\ldots]$.

Nie tylko zresztą Turcy zasługiwali w oczach autora na niepochlebne opinie; 19 września zapisał:

[...] w dalszą podróż tąż doliną Jałpy nazwanej, po której wsiami Tatarowie siedzą, ludzi u nich dosyć, ale dla swojej nieludzkości humano vix nomine $\operatorname{ding}^{23}[\ldots]$.

Podobnie ocenia we wpisie z 5 listopada zamieszkujących Turcję Greków:

[...] gdzie mnóstwo ludzi stambulskich Greków i Grekin widzieć bylo, lecz jako gens perfida ${ }^{24}$ i nigdy niegodna, bo jej i nie ma, takaż ich i ofiara, bo pełna chytrości i zdrady, lambit ut acrius mordeat ex improviso [...].

Czasem błahostka stawała się pretekstem do ironicznego prześmiewania się z inności obyczajowej; 8 listopada czytamy:

[...] prosil potym rotmistrza janczarskiego na obiad do siebie in praesentia pana Lomaki, który perfessus ${ }^{25}$ długiego na polskim stołku siedzenia prosil przez pana Lomakę aby mógł po pierwszym daniu $\operatorname{recedere~}^{26}[\ldots]$.

W zapisanych wypowiedziach autora nie tylko przejawia się niechęć do osób ze względu na ich pochodzenie etniczne, ale również pojawiają się kąśliwe uwagi dotyczące osób innego wyznania; 28 października zapisał:

21 Gens parca et pauca in loquendo (łac.) - 'lud oszczędny i lakoniczny w mowie'.

22 Parco et pauco (łac.) - 'oszczędnie i w niewielkiej ilości'.

23 Humano vix nomine digni (łac.) - 'niegodni wcale ludzkiego miana'.

24 Gens perfida (łac.) - 'lud podstępny'.

25 Perfessus (łac.) - 'zmęczony od'.

26 Recedere (łac.) - 'odejść'. 
Incolae jego, Turcy i Żydzi, chrześcijan bardzo mało, et si nomine christiano digni $^{27}$, którzy się przeżegnać nie umieją.

Inność wyznaniowa była dla autora wadą mocno piętnującą nawet ludzi szlachetnych; 21 stycznia zapisał:

$\mathrm{z}$ rana zaraz tempore missae sacrificii, która się hora $7^{m a}$ przybył z wizytą od księcia jegomości Rakoczego jegomość pan Papay, Węgrzyn i rezydent jego książęcej mości, człowiek zacny, poważny, już sędziwy, rozumny, tylko że kalwin.

\subsection{O wykształceniu autora Diariusza legarionis...}

Diariusz dostarcza pewnych wskazówek dotyczących wykształcenia autora. Wydaje się, że musiał on odebrać wykształcenie typowe dla synów szlacheckich. Notatki, które pozostawił, są przeważnie zgrabnie zredagowane, autor posługuje się zarówno językiem polskim, jak i łaciną. Zamieszczone opisy przebytej drogi, odwiedzanych miejsc, zanotowane lokalne ciekawostki sprawiają, że cały dokument nabiera po części charakteru krajoznawczego. Jego obserwacje dotyczą również napotykanych osób oraz ceremoniału dyplomatycznego odprawianego na kolejnych etapach drogi poselskiej wyprawy Sierakowskiego. Portretując w swej relacji osoby, z którymi spotykał się strażnik wielki koronny podczas podróży, autor nie tylko zwraca uwagę na ich stan i urząd, ale też przeważnie podaje dodatkowe informacje dotyczące pochodzenia, kariery czy znajomości języków.

Wydaje się, że autor jest zorientowany w bieżących sprawach politycznych kraju, przywołuje najważniejszych urzędników koronnych, wymiennie posługuje się nazwiskami i tytułami urzędników. Śladowe natomiast są odwołania do historii czy poprzednich poselstw do Stambułu. Wzmianki o nich odnaleźć można w opisie nieporozumienia, jakie zaszło w Chocimiu w sprawie aprowizacji poselstwa, kiedy mowa jest o powoływaniu się przez Turków na wykazy aprowizacyjne poprzednich poselstw, czy we wpisie z 12 października opisującym Prowadiję:

Ma kościół ormiański murowany jeden, który za interpretacją u Porty śp. jaśnie wielmożnego jegomości pana Stanisława Rzewuskiego, protunc referendarza, a potym hetmana wielkiego koronnego, ablegata stanął.

27 Et si nomine christiano digni (łac.) - ‘jeśli w ogóle można nazwać ich chrześcijanami’. 
Czytając opis wycieczki po Bosforze i zwiedzanej wówczas latarni morskiej zwanej „Dziewiczą wieżą”, możemy dostrzec kolejną wskazówkę dotyczącą odebranej przez autora edukacji. Przytacza on legendę o Leandrze i Hero, umieszczając jej akcję w odwiedzanym właśnie miejscu, a przy okazji cytuje również strofy Marcialisa, błędnie co prawda przypisując je Owidiuszowi. Znane mu więc zapewne były wydania Heroid Owidiusza, w których tzw. argumentem do listu XVIII, należącego do zbioru Nowych Heroid, bywał właśnie cytat z Marcialisa.

\subsection{O autorze - podsumowanie}

Podsumowując dotychczasowe ustalenia, można powiedzieć, że autor był szlachcicem, zapewne pochodzącym ze średniej szlachty, wykształconym, zorientowanym $\mathrm{w}$ aktualnych sprawach politycznych kraju, związanym z Józefem Sierakowskim i zaliczającym się do jego stałego otoczenia, na tyle bliskim strażnikowi wielkiemu koronnemu, że brał udział w wyprawie oraz wielu bardziej lub mniej oficjalnych spotkaniach i audiencjach polskiego posła.

Na koniec warto podjąć próbę ustalenia, czym zajmował się autor diariusza i co uzasadniało jego udział w wyprawie. Rękopis dostarcza wskazówek pozwalających przypuszczać, że autor był kimś w rodzaju osobistego sekretarza Józefa Sierakowskiego. Jego zadaniem było m.in. przygotowywanie korespondencji i relacji z wyprawy zarówno na potrzeby publikacji na łamach „Kuryera Polskiego”, jak i na potrzeby sporządzenia sprawozdania. Takie sprawozdanie poseł zwyczajowo składał po powrocie bądź to na sejmie, bądź przed kanclerzem wielkim koronnym. Relacja ta mogła być wykorzystana do przygotowania dziennika, który zarówno współczesnym, jak i potomnym zaświadczałby o zasługach Józefa Sierakowskiego dla ojczyzny.

O tym, że autor Diariusza legationis... odpowiedzialny był za przygotowanie relacji na potrzeby „Kuryera Polskiego” świadczy podobieństwo, niekiedy wręcz tożsamość obu tekstów. Jednocześnie różnice, które jednak istnieją między nimi, pozwalają wnioskować, że diariusz nie był spisany z wykorzystaniem publikacji w gazecie.

Autor, który, jak można przypuszczać, pełnił funkcję osobistego sekretarza Sierakowskiego, był też zapewne przygotowany do pracy kancelaryjnej i miał do czynienia z przychodzącą i wychodzącą korespondencją wysyłaną przez polskiego posła. Wielokrotnie we wpisach dziennych odnotowuje spędzanie czasu przez Józefa Sierakowskiego nad „ekspedycją do Polski”, zna się również na organizacji poczty:

Die 9 Ianuarii na ekspedycji do Polski jaśnie wielmożny jegomość pan strażnik wielki koronny totam consumpsit diem, ponieważ ten, który z Chocimia 
listy przywiózł d[iebus] 4 elapsis fatue cessit i przez inną okazją musiał ich ekspediować.

Zapewne zna treść niektórych listów, sam wspomina, że Jerzy Lomaka podpisał się w liście jako „faktor jego królewskiej mości”. Miał też dostęp do treści dokumentów poselstwa, o czym świadczy fragment, w którym zamiast narracji pojawia się notka o konieczności zacytowania treści innego dokumentu.

***

Prezentowane w tekście zagadnienia sygnalizują zaledwie szersze rozważania zamieszczone we wprowadzeniu do przygotowanej edycji Diariusza legationis..., dotyczące zarówno rękopisu diariusza, osoby strażnika wielkiego koronnego Józefa Sierakowskiego herbu Dołęga, posła Augusta II do Stambułu, społecznego i politycznego tła opisywanych w tej relacji wydarzeń, jak i dyplomacji polskiej czasów saskich, zwłaszcza ceremoniału dyplomatycznego.

\section{Bibliografia}

\section{Literatura}

Bukowski Andrzej (1989), Waplewo: zapomniana placówka kultury polskiej na Pomorzu Nadwiślańskim, Zakład Narodowy im. Ossolińskich, Wrocław-Gdańsk.

Cieślak Edmund (1994), Stanisław Leszczyński, Ossolineum, Wrocław.

Czamańska Ilona, Pentek Zdzisław, red. (2009), Vademecum bałkanisty. Lata 500-2007, Instytut Historii UAM, Poznań.

Dolański Dariusz (2017), Podróż z Polski do Stambułu w XVIII w., w: Staropolski oglad świata. Nulla dies sine linea. Ksiega jubileuszowa dedykowana profesorowi Bogdanowi Rokowi w 70. rocznicę urodzin, red. Elżbieta Kościk, Filip Wolański, Rościsław Żerelik, Wydawnictwo Adam Marszałek, Toruń, s. 75-90.

Dunin-Karwicki Józef (1882), Opisanie wjazdu do Stambułu Rafała Leszczyńskiego, wojewody łęczyckiego, generała wielkopolskiego, posła wielkiego od Naj. Króla Jegomości Polskiego i Rzeczypospolitej do Porty Ottomańskiej i Relacja solennej jego audjencji u Cesarza Tureckiego w 1700 roku. Spisał i ułożył ze spółczesnych źródet Józef Dunin Karwicki, „Biblioteka Warszwska”, t. 3, s. 353-370.

Dygdała Jerzy (2002), Antystanisławowska i prosaska publicystyka doby bezkrólewia 1733 roku (dzieła, autorzy, rozpowszechnianie), „Kwartalnik Historyczny”, t. 2, s. $41-59$. 
Dziechcińska Halina (1994), Kultura literacka w Polsce XVI i XVII wieku. Zagadnienia wybrane, Semper, Warszawa.

Elektorowie królów Władysława IV, Michała Korybuta, Stanisława Leszczyńskiego i spis stronników Augusta III zestawili Jerzy hr. Dunin-Borkowski i dr Mieczystaw Dunin-Wasowicz (1910), „Rocznik Towarzystwa Heraldycznego we Lwowie”, t. 1 (rok 1908/09).

Gembarzewski Bronisław (1999), Husarze: ubiór, oporządzenie i uzbrojenie 1550-1775, Arcadia, Warszawa.

Gierowski Józef (1982), Dyplomacja polska doby saskiej (1699-1763), w: Historia Dyplomacji Polskiej, t. 2: 1572-1795, red. Zbigniew Wójcik, PWN, Warszawa, s. 331-483.

Gościecki Franciszek (1732), Poselstwo Stanistawa Chomentowskiego od Augusta II do Achmeda IV, Lwów.

Górski Konrad i in.(1955), Zasady wydawania tekstów staropolskich. Projekt, Zakład im. Ossolińskich - Wydawnictwo Polskiej Akademii Nauk, Wrocław.

Kołodziejczyk Dariusz (2004a), Eacina traktatów polsko-tureckich jako element gry dyplomatycznej, w: Łacina jako język elit, red. Jerzy Axer, Wydawnictwo DiG, Warszawa, s. 399-411.

Kołodziejczyk Dariusz (2004b), Łacina w dyplomacji islamskiej: Imperium Osmańskie, w: Łacina jako język elit, red. Jerzy Axer, Wydawnictwo DiG, Warszawa, s. 395-398.

Kołodziejczyk Dariusz (2005), Postowie Rzeczypospolitej w Stambule, w: Dawne elity - stowo i gest, red. Jerzy Axer, Justyna Olko, Wydawnictwo DiG, Warszawa, s. 217-223.

Konopczyński Władysław (2013), Polska a Turcja 1683-1792, Ośrodek Myśli Politycznej, Kraków-Warszawa.

Kowalska Helena (2015), Przyczynek do historii zbiorów malarstwa hrabiów Sierakowskich w Waplewie, „Gdańskie Studia Muzealne”, t. 8: Pałac hrabiów Sierakowskich w Waplewie Wielkim. Ludzie, miejsce, kolekcja, s. 284-288.

Kraiński Maciej (2010), Panowie na Waplewie, Muzeum Narodowe w Gdańsku, Gdańsk.

Kraiński Maciej (2015), Panowie na Waplewie. Ród hrabiów Sierakowskich z Ziemi Malborskiej, „Gdańskie Studia Muzealne”, t. 8: Pałac hrabiów Sierakowskich w Waplewie Wielkim. Ludzie, miejsce, kolekcja, s. 16-35.

Krajewski Mirosław (1996-1997), Kajetan Onufry Sierakowski (1753-1841), w: Polski Stownik Biograficzny, t. 37, Fundacja na Rzecz Nauki Polskiej, Instytut Historii Polskiej Akademii Nauk, Warszawa-Kraków, s. 277-278.

Krajewski Mirosław (1996-1997), Alfons Sierakowski (1816-1886), w: Polski Stownik Biograficzny, t. 37, Fundacja na Rzecz Nauki Polskiej, Instytut Historii Polskiej Akademii Nauk, Warszawa-Kraków, s. 255-256. 
Krasiński Zygmunt (1970), Listy do Adama Soltana, oprac., wstęp Zbigniew Sudolski, Państwowy Instytut Wydawniczy, Warszawa.

Kumaniecki Kazimierz, oprac. (1990), Słownik łacińsko-polski, PWN, Warszawa.

Łątka Jerzy Siemisław (1980), Polacy w Turcji, PCKO UMCS, Lublin.

Łątka Jerzy Siemisław (2005), Słownik Polaków w Imperium Osmańskim i Republice Turcji, Księgarnia Akademicka, Kraków.

Marcjalis (2015), Księga widowisk, wstęp, komentarze Aleksandra Klęczar, Mariusz Zagórski, Instytut Studiów Klasycznych, Śródziemnomorskich i Orientalnych Uniwersytetu Wrocławskiego, Wrocław.

Mayenowa Maria Renata, Pepłowski Franciszek, red. (t. 1-34), Mrowcewicz Krzysztof, Potoniec Patrycja (od t. 35, do hasła ROWNY), red. (1966-1994), Stownik polszczyzny XVI wieku, Zakład Narodowy im. Ossolińskich, Wrocław (1966-1994), Instytut Badań Literackich Polskiej Akademii Nauk, Warszawa (od 1995).

Nowicki Ryszard (2004), Fragment biblioteki rodowej i ordynackiej Skórzewskich w Bibliotece Raczyńskich, „Biblioteka”, nr 8, s. 49-62.

Opowiadanie tego co się wydarzyło Panu Stadnickiemu rezydentowi Rzeczypospolitej przy Porcie Ottomańskiej w miesiacu sierpniu 1735 (1858), „Czas”, nr 275, s. 1-2.

Orzet i pótksiężyc. 600 lat polskiej publicystyki poświęconej Turcji (2014), red. Dariusz Kołodziejczyk, wybór, oprac. Adam Balcer, Dariusz Kołodziejczyk, Natalia Królikowska, Ministerstwo Spraw Zagranicznych, Warszawa.

Otwinowski Erazm (1849), Dzieje Polski pod panowaniem Augusta II, Kraków.

Palkij Henryk (2002), Józef Antoni Stadnicki (? - 1736), w: Polski Słownik Biograficzny, t. 41, Polska Akademia Nauk, Polska Akademia Umiejętności, Kraków, s. 398 .

Partyka Joanna (1995), Rękopisy dworu szlacheckiego doby staropolskiej, Semper, Warszawa.

Polkowski Ignacy (1873a), Album Mikołaja Kopernika. Album. Wydane staraniem Towarzystwa Przyjaciół Nauk w Poznaniu w czterechsetną rocznicę urodzin Mikotaja Kopernika, Gniezno.

Polkowski Igmacy (1873b), Żywot Mikołaja Kopernika, Gniezno.

Polkowski Ignacy $(1873,1875)$, Kopernikijana czyli materyaty do pism i życia Mikotaja Kopernika, t. 1-2, t. 3, Gniezno.

Porębski Stanisław Andrzej (1997), Paleografia łacińska. Podręcznik dla studentów, Wydawnictwo UKSW, Warszawa.

Poselstwo Rafała Leszczyńskiego do Turcji w 1700 roku. Diariusze i inne materiaty (1998), przygotowała Ilona Czamańska przy współpracy Danuty Zydorek, Urząd Miasta Leszna, Leszno.

Poselstwo wielkie Jaśnie Wielmożnego Stanisława Chomentowskiego, wojewody mazowieckiego od Nayiaśnieyszego Augusta II, krola polskiego, xiążęcia saskiego elek- 
tora y Rzeczypospolitey do Achmeta IV, soltana tureckiego wielkiego z petna moca posła z szczęśliwym skutkiem przez lata 1712, 1713, 1714 odprawione, potomnych czasów pamięci y wdzięczności podane wrzetelnym iego opisaniu przez x. Franciszka Goscieckiego, Soc. Jesu. (1732), Lwów.

Przyboś Adam, oprac. (1985), Wielka legacja Wojciecha Miaskowskiego do Turcji w 1640 r., PWN, Warszawa-Kraków.

Przyboś Adam, Żelewski Roman, oprac. (1959), Dyplomaci w dawnych czasach. Relacje staropolskie z XVI-XVIII stulecia, Wydawnictwo Literackie, Kraków.

Pułaski F. (1907), Źródła do poselstwa Jana Gnińskiego wojewody chetmińskiego do Turcji w latach 1677-1678, Warszawa.

Reczek Stefan (1968), Podręczny słownik dawnej polszczyzny, Zakład Narodowy im. Ossolińskich, Warszawa.

Reychman Jan (1959), Życie polskie w Stambule w XVIII wieku, Państwowy Instytut Wydawniczy, Warszawa.

Rodziewicz Klemens (1879), Katalog zbioru obrazów oraz innych przedmiotów sztuki znajdujacych się w posiadaniu rodziny hrabiów Sierakowskich w Waplewie (Prusy Zachodnie) sporządzony w listopadzie 1878 r. przez Klemensa Rodziewicza, Poznań. Rostworowski Emanuel (1994), Historia powszechna wiek XVIII, PWN, Warszawa.

Róg Rafał (1996-1997), Sebastian Sierakowski (1743-1824), w: Polski Słownik Biograficzny, t. 37, Fundacja na Rzecz Nauki Polskiej, Instytut Historii Polskiej Akademii Nauk, Warszawa-Kraków, s. 293-299.

Rzepka Wojciech Ryszard, Walczak Bogdan (1992), Socjolekt szlachecki XVII wieku (Próba ogólnej charakterystyki), w: Barok w polskiej kulturze, literaturze i języku. Materiaty z konferencji naukowej 25-29 sierpnia 1987 r. w Krakowie, red. Marian Stępień, Stanisław Urbańczyk, PWN, Warszawa-Kraków, s. 179-189.

Rzyska-Laube Dobromiła (2015), Zaginiona kolekcja. Nowe ustalenia na temat zawartości zbiorów Sierakowskich z Waplewa oraz ich wojennych i powojennych losów, „Gdańskie Studia Muzealne”, t. 8: Pałac hrabiów Sierakowskich w Waplewie Wielkim. Ludzie, miejsce, kolekcja, s. 122-165.

Semkowicz Władysław (1951), Paleografia łacińska, Polska Akademia Umiejętności, Kraków.

Siniarska-Czaplicka Jadwiga (1969), Filigrany papierni położonych na obszarze Rzeczypospolitej Polskiej od poczatku XVI do połowy XVIII wieku, Zakład Narodowy im. Ossolińskich, Wrocław.

Siniarska-Czaplicka Jadwiga (1977), Papier druków tłoczonych na Mazowszu i Podlasiu w XVI-XVIII w., „Kwartalnik Historii Kultury Materialnej”, nr 2, s. 217-242.

Siniarska-Czaplicka Jadwiga (1983), Katalog filigranów czerpalni Rzeczypospolitej zebranych z druków tłoczonych w latach 1500-1800, Stowarzyszenie Inżynierów i Techników Przemysłu Papierniczego w Polsce, Komisja Wydawnicza, Łódź. 
Stownik geograficzny Królestwa Polskiego i innych krajów stowiańskich, wyd. pod red. Filipa Sulimierskiego, Bronistawa Chlebowskiego, Józefa Krzywickiego, Władystawa Walewskiego (1880-1914), t. 1-15, Warszawa.

Stownik języka polskiego XVII i 1. połowy XVIII wieku (1996), Instytut Języka Polskiego Polskiej Akademii Nauk, Kraków.

Szklarska Ewa (1996-1997), Sierakowski Józef h. Dotęga, w: Polski Słownik Biograficzny, t. 37, Fundacja na Rzecz Nauki Polskiej, Instytut Historii Polskiej Akademii Nauk, Warszawa-Kraków, s. 268-269.

Szklarska Ewa (2002), Jan Stadnicki (zm. 1766), w: Polski Stownik Biograficzny, t. 41, Polska Akademia Nauk, Polska Akademia Umiejętności, Kraków, s. 392-393.

Szulc-Golska Bożenna (1929), Wielkopolskie bibljoteki prywatne, w: Bibljoteki wielkopolskie i pomorskie, red. Stefan Wierczyński, Komitet Organizacyjny IV Zjazdu Bibljofilów i II Zjazdu Bibljotekarzy Polskich, Poznań, s. 227-269.

Szymański Józef (2004), Nauki pomocnicze historii, PWN, Warszawa.

Świderkówna Anna, red. (1990), Stownik pisarzy antycznych, Wiedza Powszechna, Warszawa.

Świerkosz Krystyna (2015), Z historii poszukiwań rozproszonej biblioteki waplewskiej w zbiorach Biblioteki Gdańskiej PAN, „Gdańskie Studia Muzealne”, t. 8: Pałac hrabiów Sierakowskich w Waplewie Wielkim. Ludzie, miejsce, kolekcja, s. 240-272.

Tarnowski Stanisław (1882), Z Prus Królewskich, Drukarnia „Czasu”, Kraków.

Tarnowski Stanisław (1894), Z wakacyj. (Prusy Królewskie), t. 2, Księgarnia Spółki Wydawniczej Polskiej, Kraków.

Topolski Jerzy (1999), Polska w czasach nowożytnych (1505-1795), Wydawnictwo Naukowe Uniwersytetu im. Adama Mickiewicza, Poznań.

Trzy relacje z polskich podróży na Wschód muzulmański w pierwszej połowie XVII wieku (1980), wybór, wstęp, oprac. tekstu, komentarze Adam Walaszek, Wydawnictwo Literackie, Kraków.

Urbańczyk Stanisław i in., red. (1953-2003), Stownik staropolski, t. 1-11, Instytut Języka Polskiego Polskiej Akademii Nauk, Kraków.

Voorn H. (1960), De papiermolens in de provincie Noord-Holland, De Papierwereld, Haarlem.

Waliszewski Kazimierz (1894), Ostatni poset polski do Porty Ottomańskiej. Akta legacji stambulskiej Franciszka Piotra Potockiego, starosty szczerzeckiego, t. 1-2, Imprimerie Vevue Victor Goupy, Paryż.

Żychliński Teodor (1879), Zlota księga szlachty polskiej. Rocznik pierwszy, Jarosław Leitgeber, Poznań.

Prasa

„Kuryer Polski” 1730, nr XX. 
„Kuryer Polski” 1732, nr CXLII, CXLIII, CXLV, CXLIX, CL.

„Kuryer Polski” 1733, nr CLIX, CLX, CLXI, CLXIV, CLXV, CLXVI, CXXIII, CLXXV, CLXXVIII, CLXXX, CXC.

Zasoby archiwalne (wraz ze skrótami stosowanymi w tekście)

AGAD - Archiwum Główne Akt Dawnych.

APP - Archiwum Państwowe w Poznaniu.

APP, zespół Majątek Czerniejewo-Skórzewscy, układ fidekomisowy, 53/931/0/4.1/2095. APP, zespół Majątek Czerniejewo - Skórzewscy, Wykaz dzieł sztuki w Czerniejewie sporządzony w związku z utworzeniem fidekomisu, 53/931/0/4.1/2095.

Archiwum Państwowe w Gdańsku, Akta Sierakowskich z Waplewa, powiat sztumski, sygn. $10 / 1000 / 0$.

Michał Rzepka

On the Editorial Work on Diariusz legationis JWJMci Pana Strażnika Wielkiego Koronnego odprawionej roku 1732

In this article, the author merely indicates the selected results of the work on the edition of Diariusz legationis JWJMci Pana Strażnika Wielkiego Koronnego odprawionej roku 1732 (The diary of the 1732 diplomatic journey of Crown Great Guard) kept in the archives of Adam Mickiewicz University Library in Poznań. The research carried out in order to prepare the editorial work presented in this article was focused on the authenticity, source and the author of the text. The analysed diary is a late-eighteenthor early-nineteenth-century copy of an earlier version made between 1744 and $1826-$ which is when it was acquired for the library of Czerniejewo-Radomice owned by the Skórzewski Counts. It was dated as a result of research that covered such issues as the paper it was written on, the watermarks in it and the entries describing its origin. The copy was made in a manor, most likely in Waplewo Wielkie owned by the Sierakowski family of the Ogończyk coat of arms.

It has been determined that apart from the copy kept in the University Library in Poznan and a related record of the diplomatic journey published in Kuryer Polski (Polish Courier) from 1732 to 1733 , there were at least two versions of the text: a diary included in the collection of Waplewo library and the original it was a copy of, which could be both the diary and additional documents and letters related to the diplomatic journey.

KEYwORDS: Józef Sierakowski; diplomatic journey to Istanbul; diary; edition; PolishTurkish relationships in the 18 th century; Polish 18th-century diplomacy. 
dr Michał Rzepka - Wyższa Szkoła Języków Obcych im. Samuela Bogumiła Lindego, doktor nauk humanistycznych w zakresie literaturoznawstwa (praca doktorska Diariusz legationis JWJMości Pana Strażnika Wielkiego Koronnego odprawionej roku 1732. Edycja tekstu, przygotowana pod kierunkiem prof. dr. hab. Wiesława Wydry); zainteresowania badawcze: historia i kultura polskiego baroku oraz edycje źródeł historycznych. 
